\title{
CORPORATE GOVERNANCE: SHAREHOLDERS' INTERESTS' AND OTHER STAKEHOLDERS' INTERESTS
}

\author{
Elena F Pérez Carrillo*
}

\begin{abstract}
Much of the traditional Company Law doctrine considers that Corporations must be managed to promote, above all, shareholders' rights. Activities in favour of non-shareholder constituencies such as suppliers, consumers, employees or the Community at large can be perceived as a means of Management to increase its power and personal prestige. Stakeholders' interests can be interpreted as opposing Shareholders rights to obtain fair revenue for their investment. In this paper, we argue that Shareholders and Stakeholders interests are compatible and both contribute to corporate long term efficiency and progress. It is further argued that it is essential to achieve a wide consensus on how to control Management actions in support of Stakeholders interests.
\end{abstract}

Keywords: Shareholders, Stakeholders, Corporate Social Responsibility, Corporate Social Citizenship, Corporate Social Practices Reporting

* Universidad Santiago de Compostela

\section{Introducion}

Much of the world's public attention of the early years of the XXIst century had it origin in failures within Big Multinational Corporations such as Enron or Parmalat, that evidenced that the functioning of certain elements of late XXst century Corporate Governance models based on maximisation of shareholder's interests, were not able to ensure sustainable development of Corporation activities ${ }^{1}$.

Corporate governance through the protection of a wider set of interests can be regarded as an alternative way of efficiently conducting Corporate Governance. Taking into consideration other stakeholders' interests is often regarded as fairly recent in development, and Freeman is generally cited as its landmark. However neither this idea nor many of its practices are new. From a philosophical standpoint it has been related with expansion of democratic ideas $^{2}$. From a practical perspective,

${ }^{1}$ Questions considered as underlying failures include lack of control by auditors and other gatekeepers, director's remuneration packages, and other elements organised around the pivotal ideas of short term maximisation of investment and lack of business ethics. Buchholz R.A, and Rosenthal, S B "Social responsibility and Business Ethics" en Frederick RE (Ed), A Companion to Business Ethics, Massachusetts, Blackwell Publishers, 2002. Sen, A On Ethics and Economics, Blackwell, Oxford, 1987.

2 Taking shareholders' interests into consideration in the Corporations" decision making processes has been linked to a "democratic idea" H Hummels, "Organising Ethics: A Stakeholder debate", Journal of Business Ethics, October, Vol 17 (13) 1998, pages 1403-1419. This interpretation is criticized as it is over idealistic and utopic, see D A Gioia, "Practicability, paradigms, and problems in stakeholder theorising", The Academy of Management Review, Vol 24 (2)1999, pages 228-232. Others 96
XIXth century chocolate manufacturers in Europe devised ethics codes and built model factories to the benefit of their workers, supplied health and adult education facilities and reduced the length of working week. In the USA pharmaceutical such as Merck developed Codes of conduct, which underlined the Corporation's goal to serve public health. These two are just a sample of Corporations' respect for constituents other than shareholders ${ }^{3}$.

More recently, academic and practical interest for "other constituencies" approach to Corporations' management has evolved in parallel with the critics of Corporate Governance theories that evolve around the maximisation of short-term revenue to shareholders. It has occupied much of the academics works in the last decade. Sometimes it appears "hidden" behind terms such as Corporate Social Responsibility, corporate citizenship, corporate accountability, or triple bottom line (of environmental social and financial reporting), in other occasions it is used as a rebrand to

criticise the idea that all stakeholders are equal and explains that such an idea would tend to mistakenly deal with business as with government. (E Sternberg, Just Business: Business Ethics in Action, Little, Brown and Company, London, 1994). Others have argued that implementation of igualitarian ideas would demand great efforts to identifying stakeholders and to determining which should receive what portion of management time $\mathrm{S}$ Cooper, Corporate Social Performance: A Stakeholder Approach, Ashgate Publishing Cia, London-Hants, UK, pages 20-21.

${ }^{3}$ One of the best known academic works that favoured the taking into consideration of "other constituencies" in the decision taking process of corporations is Dodd, E.M. "For whom are Corporate Managers Trustees? Harvard Law Review, num. 45, 1932, Pages. 1145 and following. 
Corporation's charities and donations. Many Corporations have started to formalise their practices and to publicise them ${ }^{4}$. Most Fortune 500 companies make their Social practices known through their Web sites and Public Relations materials, and have adopted policies and codes and have acted in consonance with the goals of sustainable good governance. It is difficult to decide whether they have acted simply in order to promote their contribution to community development or to gain and sustain a competitive advantage. The Body Shop promotes community trade, opposes animal testing, defends human rights, and protects the environment ${ }^{5}$. Ford and General Motors have established 'green' procurement guidelines and announced that they expect their suppliers to conform to the ISO 14001 EMS standard ${ }^{6}$. Novartis was awarded the 2004 Excellence in Corporate Philanthropy Award by the Committee to Encourage Corporate Philanthropy $(\mathrm{CECP})^{7}$. Bill \& Melinda Gates Foundation was granted the 2006 Principe de Asturias Price for their efforts in the areas of global health, education, and culture ${ }^{8}$. In the UK, several big companies such a as Virgin or British Sky Broadcasting are currently making statements to the

${ }^{4}$ D.Kinley, J Tadaki, "From Talk to Walk: The Emergence of Human Rights Responsibilities for Corporations at International Law”, 44 VA. Journal International Law pages 931, 953, 2004. D Cassel, "Corporate Initiatives: A Second Human Rights Revolution?", 19 Fordham International Law Journal, pages 1963 - 1978 (1996). Warner, E, “Bosses saving our planet can't ignore the bottom line. The Daily Telegraph, business Centre $20^{\text {th }}$ September 2006, page B 6. Graved, M., Ownership and Influence, Interdisciplinary Institute of Management, LSE, London, 1995, page 8. Hirsch, F Social Limits to Growth, Routledge and Kegan Paul, London and Henley, 1978.

5 The Body Shop, Our Values, http:// www.thebodyshop international.com/web/tbsgl/values.jsp (last visited Jan. 4, 2006);

${ }^{6}$ The International Organization for Standardization (ISO) is the world's largest developer of standards. ISO 14001 belongs to the ISO 14000 family of standards, which is primarily concerned with "environmental management," for example, what a business organization does to "minimize harmful effects on the environment caused by its activities." International Organisation for Standardization (ISO), ISO 9000 and ISO 14000--In Brief, http://www.iso.org/iso/en/iso9000- 14000/understand/inbrief.html (last visited Mar. 23, 2006); see also ISO, Business Benefits of ISO 14001, http://www.iso.org/iso/en/prods-services/otherpubs/ iso14000/businessbenefits.pdf (last visited Mar. 23, 2006).

Novartis, http:// www.novartis.com/corporate_citizenship /en/index.shtml (last visited Feb. 25, 2006). Novartis recently announced its commitment to provide free drugs to all leprosy patients worldwide through 2010.

${ }^{8}$ Niskanen, W A (ed) After Enron: lessons for public policy, Lanham, New York, 2005. See also The Gates Foundation's Global Health Program's mission "is to ensure that people in the developing world have the same chance for good health as people in the developed world. We see a tremendous opportunity to save millions of lives through the development and distribution of health tools and strategies--some new, some already in use." Bill \& Melinda Gates Found., Global Health, http://www. gatesfoundation. org/GlobalHealth/ (last visited Feb. 26, 2006) On the other hand, the Global Libraries program "seeks to increase access to technology for residents in low-income and disadvantaged communities through partnerships with public libraries in the United States and throughout the world." Bill \& Melinda Gates Found., Global Libraries Program, http:// www.gatesfoundation.org/Libraries. effect that they are engaging in socially responsible activities and reinvestment? Spain has known a similar phenomenon. The in-depth study recently completed by Fundación Empresa y Sociedad in relation with Corporate Social Responsibility practices of big Spanish Companies ${ }^{3}$ shows that most of them -Altadis, BBVA, Endesa, Ferrovial, Gas Natural, BSCH, Iberdrola, Iberia, Inditex, Indra, REE, Repsol-YPF, Telefónica, Prisa, Recoletos and Sol Meliá among others- included their Social practices within their annual report ${ }^{10}$.

\section{Conflicting interests}

Corporate Governance deals with Corporations organisation and decision making structures. One of its main purposes is to ensure the efficient confluence of otherwise competing interests that are affected by Companies' activities. The debate about the relationship between shareholders' interests (those of investors and owners of the issued shares of the Corporation) and other stakeholders' or "other constituents" interests (those related to a varied number of constituencies such as employees, citizens of the Community where the Corporation interacts, etc) is as old as Corporations. It is rooted on different theories that support the idea of legal persons (firms, Corporations, etc.). The modern discussion about this dichotomy goes back at least to the early years of XXst century and to the influential works of Berle, Dodd and other Professors of the time ${ }^{11}$. Attention paid to corporate behaviour nowadays, comes from the increased freedom granted to Corporations to develop their business activities and the need that this freedom is used wisely and responsibly.

There can be are many perspectives to view Corporation's practices of promotion of constituencies other than shareholder's interests. We link them to two competing theory of Corporate Governance: shareholders theory (agency) and stakeholder's theory.

Shareholders' theorists of Good governance tend to follow Milton Friedman statement that social responsibility of business is to increase business and consider that shareholders interest in the increase in value of their shares is paramount of Corporations

${ }^{9}$ Profits from Virgin rail and air business are being used to find alternative fuel by Virgin Fuels, and Mr Murdoch's BSyS has set his empire the goal of becoming the first media company in the world to be carbon neutral. Warner, E, "Bosses saving our planet can't ignore the bottom line. The Daily Telegraph,business Centre $20^{\text {th }}$ September 2006, page B 6 .

${ }^{10}$ FES (2003): Las empresas mejor percibidas por su acción social. Ranking 2003. FundaciónEmpresa y Sociedad, Madrid [http://www.empresaysociedad.org].

${ }^{11}$ The debate between Shareholders' interests and Stakeholders' interests was very precisely set on the exchange of articles between Professors Berle and Dodd early last Century: Berle, A. "For Whom Corporate Managers Are Trustees" Harvard Law Review, num. 451932 , pages 1365 and following, Dodd, E.M. "For whom are Corporate Managers Trustees? Harvard Law Review, num. 45, 1932, pages. 1145 and following. 
goals $^{12}$. This conception implies that Company's Directors and Executives act as agents of the shareholders, and should use Corporation's resources only for their principal's benefit. Further, it is said that left to their own, agents would pursue their own interests. Actions to promote "Community interests" are seen, as a way for Manager's to promote their own strength and prestige, and to expropriate shareholders of their resources. Shareholders' theorists are favourable to acknowledging shareholders rights over decisions on how their investment is used, and are concerned by the information asymmetry between the principal and the agent ${ }^{13}$. These lines of thought are often based on the idea of perfect and efficient markets ${ }^{14}$ that can be rooted in some of the main Utilitarian philosophers such as Bentham who advocated the pursuance of self-interest to maximize utility. Adam Smith's economic theory is seen as leading a similar strategy for business. He considered that business acted in a self-interested manner, that the market place would regulate their behaviour and that its "invisible hand" would ensure social benefit. Shareholders' theories underline that Directors and Officers of Public and Private Companies owe fiduciary duties only to shareholders, to whose benefit they must manage Corporations' business. Protection of other interests is located beyond their duties, except in those situations where they are contractually compelled to do so. These theories acknowledge the relevance of investor's input into the company. However, taken in absolute terms, they can lead to abuse of shareholders' rights and can contribute to the longterm instability of Companies.

Those advocating in favour of taking into account interests other than those of shareholders in the Corporation's decision making process, favour giving stakeholders other than shareholders an independent right to influence Companies activities $^{15}$. Corporation's theories and practices to support shareholder's interests are generally based on the identification of many different factions

${ }^{12}$ Friedman, M Capitalism and Freedom. University of Chicago Press, 1962

${ }^{13}$ This asymmetry makes it difficult to guarantee whether the agents have fulfilled their duties to shareholders and whether the later have had their instructions followed and their aims achieved. Agency Theory is prevalent in Anglo-Saxon Common Law countries. It is said that managers to a business have a fiduciary duty to Shareholders. This fiduciary duty is interpreted by some in a very narrow sense (implying a duty of maximisation of the Corporation Shareholders' investment), and lately in a wider form by means of suggesting that fiduciary duties simply require that the fiduciary has an open and honest relationship with the shareholders and does not extract illegitimate benefits from his or her office.

14 Druker, P "The new meaning of Corporate Social responsibility", California Management Review, pages 53-63. 1994, number 26. Jensen, M "Corporate Control and the Politics of Finance", Journal of applied corporate finance, Vol 20(2) 1991, pages 13-33.

${ }^{15}$ D Ronnegard, Corporate Moral Agency and the Role of the Corporation in Society, London School of Economics, 2006. (Unpublished theses, on consultation)

98 within society to whom Companies may have some responsibility, and on the prediction of how businesses should operate in order to care, not only for their shareholders economic profitability, but also for others.

The definition of "other constituents" or stakeholders is wide and there is not a general consensus on it. Some encompass within it all those groups without whose support the organisation would cease to exist. Others widen the boundaries of the definition to include any individual or group who can affect or be affected by the achievement of the organisation's objectives ${ }^{16}$.

Taking shareholders' interests into consideration in the Corporation's' decision making processes has been linked to a "democratic idea" similar to that of Tocqueville in Democracy in America, 1835 in so far as each group is considered equal to the other ${ }^{17}$. However, this interpretation is to be criticized as it is over idealistic and utopic ${ }^{18}$.

\section{Conciliation of interests}

Balance between the different groups of stakeholders is essential to the long-term viability of the Corporation. Fair and balanced stakeholder's perspective results in long-term shareholder maximization value ${ }^{19}$. Good Corporate Governance is about reconciliation of otherwise diverging interests. The dichotomy we have described sets its roots in long standing philosophical traditions. In our view it is also entrenched in unrealistic theories. Shareholders short-term maximisation of wealth leads to system abuses, such as we have seen in the

\footnotetext{
16 S Cooper, Corporate Social Performance: A Stakeholder Approach, Ashgate Publishing Cia, London-Hants, UK, Pages pages 21-22, citing other authors particular Freeman.

7 Hummels, H., "Organising Ethics: A Stakeholder debate", Journal of Business Ethics, October, Vol 17 (13) 1998, pages 1403-1419.

18 Gioia, D A "Practicability, paradigms, and problems in stakeholder theorising", The Academy of Management Review, Vol 24 (2)1999, pages 228-232. Also Sternberg E, Just Business: Business Ethics in Action, Little, Brown and Company, London, 1994. Others have argued that its implementation would demand great efforts to identifying stakeholders and to determining which should receive what portion of management time Cooper, S, Corporate Social Performance: A Stakeholder Approach, Ashgate Publishing Cia, London-Hants, UK, pages pages 20-21.

${ }^{19}$ R S Kaplan and D P Norton, "The Balanced Scorecard Measures That Drive Performance", Harvard Business Review, January-February, 1992, pages 71-79. , R S Kaplan, and D P Norton, The balanced Scorecard: Translating Strategy into Action, Harvard Business School Press, Harvard 1996. R S Kaplan, and D P Norton, "Using the Balanced Scorecard as a Strategic Management System", Harvard Business Review, January-February, 1996, pages 75-85. These leading authors on management strategies points at the fact that to achieve a correct and efficient balance, businesses are to obtain positive valuation from 4 perspectives: customer perspective, internal perspective, innovation and learning perspective, and financial perspective. Shareholders, taken into account within the financial perspective, and customers are two specific stakeholders. Innovation would imply the need for employee development. Supplier relations
} should be incorporated within the internal-business perspective. 
dramatic financial scandals through history, namely in the early years of XXI century. Stakeholders' interest maximisation can lead to Corporation's assets waste and diversion. Governance analysis must serve as a means to organise, structure and to establish an efficient prioritisation of interests.

Stakeholder's movement contains a prescription for corporations to pursue ends that go beyond the single interests of shareholders and means that Directors and Officers are to care for the interests of others involved in the company activity. In doing so, shareholders long term interest are also benefited: increasingly consumers prefer to buy products from companies they trust, suppliers are interested in business partnerships with companies they can rely on; employees rather work for companies they respect; large investment funds favour socially responsible firms ${ }^{20}$; and most respected NGOs prefer to cooperate with companies conciliating their investment interests with Community goals ${ }^{21}$.

Corporate managers are, in accordance this view, to reconcile stakeholders and shareholders' needs and interests though strategies capable to raising both economic and social and environmental standards. If the decision making process within corporate hierarchies were captured and controlled by one set of stakeholders, other stakeholders might eventually cease to cooperate, to withhold inputs in the future, and try to withdraw inputs over which they have influence. The complex nature of modern corporations implies that shareholders investment is better protected though the care and respect of those "external" assets. Breaches of social or environmental laws bring penalties and sanctions to Corporations and diminish shareholder's revenues. In the absence of imperative laws, lack of respect for social, environment issues can have disastrous consequences for the Corporation's activities and profitability.

Considered in the medium or large term, bona fide interests of most stakeholders coincide with those of shareholders and the Company: Customers and clients are stakeholders whose satisfaction is a great challenge to the Corporation. No company can create great wealth for its shareholders without a stable and growing revenue base, which comes from customers. As long as management invests in higher levels of customer satisfaction that earns an economic return, there is no conflict between maximizing shareholder value and maximizing customer satisfaction. Suppliers are crucial to developing and implementing strategies that generate wealth. Attempts to pay prices that are below market levels may allow achieving a greater short term profit. They are also likely to lead to supply disruptions or quality problems. Management

${ }^{20}$ Social investment funds seek to invest in economic activities consistent with a particular social agenda.

${ }^{21}$ W B, Jr Werther and D Chandler, Strategic Corporate Social Responsibility. Stakeholders in a Global environment, Thousand Oaks (California)- London, 2006, Pages 6-9. systems are based upon cooperation with suppliers to improve quality, delivery-production schedulesand inventory. Those exercises help raising both suppliers' profits and value for shareholders. Maximizing value for shareholders demands enlightened staff. Companies that pay their employees below market, or deal with their employees in ways which undermine their talents are wasting valuable assets and are not maximising wealth for shareholders. Corporations with good human resource records are in a better position to achieve long-term profitability. Corporation's prestige in the Communities where they interact helps in achieving long-term cooperative relationship. This is, too, a good ground for long term wealth maximisation.

\section{Control}

In the preceding section we have praised some of the benefits deriving from Stakeholders' theories of Corporate Governance. However, taking into account other constituencies is capable of placing management in a position in which wasting Corporations assets is easily disguised as "Good Corporate Citizenship". Actions in favour or clients, consumers, workers or even communities at large must be placed under control, and are to be exercised by taking into account long term benefit of the Company in accordance with what has been stated by shareholders in their incorporation chart, and internal regulations. Corporation's expenses and investment towards stakeholders are to form an integral part of the Governance strategy, be placed under scrutiny by Corporations Committees, such as the Audit Committee, be timely and precisely explained to shareholders and be consistent with the Corporation's general programme and stated Action Plans. Company accounts and governance reports must reflect expensed incurred, together with an explanation of their aims and strategic approach to achieve them. Furthermore, promotion of stakeholders' interests ought to be subject to a uniform and standard reporting model. This has not, to date, been put into place.

Far from a unique reporting model, there are various proposed schemes for Companies to inform the public about their Corporate Social practices. Most are leaded by International Organisations and are clearly orientated to promoting good corporate behaviour in underdeveloped countries. None of them are compulsory. One of the best known is UN Global Compact, which was launched in 1999. Compact is based on internationally accepted principles of labour standards, human rights and environmental protection $^{22}$. The International Labour Office (ILO) tripartite declaration of principles

${ }^{22}$ It has no proper verification mechanism and companies can simply demonstrate their adherence to the code by publicising their support on the UN's website and in their annual reports. NTERPRESS 
governing multinational enterprises and social policy declaration dates from 1977 provides guidelines for governments business and workers on issues such as employment, training, conditions of work and industrial relations ${ }^{23}$. The OECD guidelines on multinational enterprises were first drafted in $1976^{24}$ and they cover issues from child and forced labour, environmental and technical problems such as how to encourage suppliers to major companies to follow the guidelines. Global reporting initiative (GRI) was set up in 1999 to guide business on reporting their economic, environmental and social activities; it is voluntary and does not monitor compliance. Social Accountability 8000 is a monitoring and certification scheme designed to monitor labour standards in global manufacturing operations ${ }^{25}$. EMAS (Ecomanagement and Audit Scheme) is a quality assurance scheme for environmental management endorsed by the European Union Commission. ISO 14000 is an environmental management standard, monitored by the International Standards Organisation. All these schemes are an excellent starting point towards the definition of a comprenhesive global and generally accepted reporting system, however they are insufficient in terms of achieving a real monitoring and control effect.

There are too, some regional attempts to grant uniformity to social responsibility practices and reporting initiatives.

In USA, traditional state and corporate law doctrine establishes that Directors and Officers of both public and private Companies owe fiduciary duties to shareholders alone. Directors and officers must manage for the exclusive benefit of its shareholders. However, this has been reformed in a majority of states that authorizes Directors to take into account the interests of other "constituencies" such as employees, suppliers, customers, and the local community in making business decisions. These a known as other constituencies statutes. Some apply to all Director decisions, while others apply only to decisions about mergers ${ }^{26}$. Some permit Directors to consider the interests of other

23 Labour Organisation, Tripartite Declaration of Principles Concerning Multinational Enterprises and Social Policy, November 2000, available at http://www.ilo.org/public/ english/employment/multi/download/english.pdf.

${ }^{24}$ The OECD Guidelines for Multinational Enterprises, June 27, 2000, available at http://www.oecd.org/ dataoecd/56/ 36/1922428.pdf.

${ }^{25}$ The International Organization for Standardization (ISO) is the world's largest developer of standards. ISO 14000 family of standards are primarily concerned with "environmental management". See http://www.iso.org/iso/en/iso 9000 14000/understand/inbrief.html

${ }^{26}$ Pennsylvania in late 1983 was the first state to adopt a statute that specifically authorized directors to consider the interests of groups other than shareholders in making decisions. Since then, most of the rest states have adopted similar laws: Arizona, Connecticut, Florida, Georgia, Hawaii, Idaho, Illinois, Indiana, Iowa, Kentucky, Louisiana, Maine, Massachusetts, Minnesota, Missouri, Nebraska, New Jersey, New Mexico, New York, Ohio, Oregon, Tennessee, Wisconsin, and Wyoming. constituencies, without further cualification, while others limit the Directors' concern to the long-term and short-term interests of shareholders, but allow the Directors to define the shareholders' long-term interests as including the welfare of other groups. All of these statutes, however, generally expand the directors' discretion in making corporate decisions. As regards jurisprudence, some leading cases support, under precise circonstances, the "other constituencies view". In Dodge v. Ford Motor Co. ${ }^{27}$, Directors were accused of subordinating shareholder interests to other interests. In that case, the Directors, dominated by Henry Ford, refused to pay dividends and instead reduced the price to consumers. Michigan Supreme Court affirmed that Directors decission did not sacrifice shareholders' interests. In Unocal Corp. v. Mesa Petroleum Co. ${ }^{28}$, the court declared that a takeover defense must be "reasonable" and that the directors' determination of reasonableness entails an analysis of the nature of the takeover bid and its effect on the corporate enterprise. The Supreme Court of Delaware added that the Directors may consider are "the impact on 'constituencies' other than shareholders, such as, creditors, customers, employees, and the community generally. It underlined, however that they could not do so at the expense of shareholders. In Revlon Inc. v. MacAndrews \& Forbes Holdings, Inc. ${ }^{29}$, the Delaware Supreme Court described the possibility of a board of Directors to take account of the interests of "various corporate constituencies"' in more limited way stressing that in doing so there must be some benefit to stockholders. Although it seems contrary to traditional Corporate Law, in many ways, the corporate constituency statutes reflect the early and traditional jurisprudence relating to director obligations, which made it clear that a director's sole duty was to the corporation and not the shareholders ${ }^{30}$. Notwithstanding these laws and Court decisions, the debate is open and support of non-shareholders' interests is frequently criticised.

At the European level the concern for Corporations Social Responsibility can be traced at least back to the nineties ${ }^{31}$. The European

${ }^{27}$ Dodge v. Ford Motor Co, 204 Mich. 459, 170 N.W. 668 (1919).

${ }^{28}$ Unocal Corp. v. Mesa Petroleum Co ., 493 A.2d 946 (Del. 1985).

${ }^{29}$ Revlon Inc. v. MacAndrews \& Forbes Holdings, Inc 506 A.2d 173 (Del. 1986).

${ }^{30}$ Steven M.H. Wallman, "The Proper Interpretation of Corporate Constituency Statutes and Formulation of Director Duties", 21 Stetson Law Review 163, 166 (1991)

${ }^{31}$ At European Union institutional level, there has been a deep debate on the need to take into account stakeholders' interest into Corporations' decision making processes. This is perceived as a way to secure sustainable development ands social justice. In 1993, the EU began to debate whether it should develop a strategy to promote Corporate Social Responsibility and the Commission published a paper asking businesses to help tackle social exclusion. On 1996, a number of European Business Leaders and the Commission teemed up to establish corporate social and environmental concerns in Europe in 1996, an organisation that provides links between European Union member States and Corporate Social Responsibility based organisations representing TTERESS 
Commission published a Green Paper on possible ways to promote Corporate Social Responsibility in $2001^{32}$. In it 2002 made public its aspiration for Corporate Social Responsibility to contribute to making Europe by 2010 the most competitive and dynamic knowledge based economy in the world, capable of sustainable economic growth with more and better jobs and a greater social cohesion ${ }^{33}$. In March 2006 the EU Commission launched a new Communication to bring social and environmental concerns, to the centre stage on strategic sustainable development and growth ${ }^{34}$. European Union plays a role in setting trade, aid, environmental and social policies, which are directly related to Stakeholders' interests' protection and Corporate Social Responsibility. Member States can find that national attempts to promote an alliance between Shareholders' and Stakeholders' interests through fiscal incentives or social labelling schemes-often may be in breach of the European Union single market rules ${ }^{35}$. There are, therefore, strong reasons why Europe should develop a common approach to corporate social responsibility as it provides a forum for governments and business to exchange information and share best practice ${ }^{39}$. Stakeholders' interest and Corporate Social Responsibility are being promoted on a European supranational field. This, together with the Principle of Subsidiary ${ }^{40}$, implies that works concentrate on those fields in which Community involvement is an advantage $e^{41}$. Works are also, to date, based on voluntary proposals, thus meaning that to be socially responsible, business are to go "beyond" the fulfilment of their legal duties. The voluntarily approach of the EU Commission does not eliminate hard law legislation that regulate business. In fact, it is argued that, should a strong and reliable hard legal

around 1500 business.

${ }^{32}$ European Commission. Promoting a European framework for Corporate Social Responsibility

Green Paper, Brussels, 18.01.2001. COM (2001) 366 final.

33 "Communication from the Commission concerning Corporate Social Responsibility: A business contribution to Sustainable Development", Brusels 02.07.2002, COM (2002) 0347 final.

${ }^{34}$ European Commission, "Communication from the Commission concerning Corporate Social Responsibility: A business contribution to Sustainable Development”, Brusels 02.07.2002, COM (2002) 0347 final. Also European Commission, "Implementing the partnership for Growth and Jobs: making Europe a pole of Excellence on Corporate Social Responsibility" Brussels 22.03.2006. COM (2006) 136 final.

35 Murray, A, Corporate Social Responsibility in the Europe Union, Centre for European Reform, London, 2003.

${ }^{39}$ Perez Carrillo, E F "Gobierno corporativo en Europa como instrumento de atracción de inversiones y de responsabilidad social", Revista Criterios, Instituto de Estudios Politicos y Sociales, vol. 52005.

${ }^{40}$ Subsidiary is one of the main ruling principles of European Community and it is reflected on Art 5 of the European Union Treaty. This explicit reference was introduced in 1992 by the Maastricht Treaty.

${ }^{41}$ European Commission, "Communication from the Commission concerning Corporate Social Responsibility: A business contribution to Sustainable Development", Brussels 02.07.2002, COM (2002) 0347 final. In particular page 9. framework not exist, it must be put in place as a first step to protect Stakeholders interests such as labour, environment, etc. ${ }^{42}$.

\section{Conclusions}

In this paper we have revisited a debate made classic in the 1930s, which has been reinforced as a consequence of XXI century scandals and is active today.

Whilst Governance Shareholder model can be considered hegemonic, an emerging area of "progressive" corporate law scholarship challenges the dominant paradigm. Stakeholders' theories are based on prescriptions for corporations to pursue ends that go beyond the single interests of shareholders. They have been criticised on the basis that making Directors accountable for multiple constituencies would increase managerial discretion. However, taking into account that shareholders have already little say in the decision-making processes of Corporations, that seems an empty argument.

The debate between the two models is traditionally presented a sharp dichotomy. In attempting to negotiate the tensions between both, we are to choose between either maximizing shareholder wealth or caring for other interested parties too. However, it can be argued that this divide is fallacious. A Company's Corporate Social Responsibility record has an impact on the bottom line through its effect on the company's reputation. This has persuaded many Big Corporations to maintain a known record of Social and environmental activities.

Corporations' acknowledgement of their Social Responsibilities can be very satisfactory for Shareholder's long-term interests. Bona fide interests of most stakeholders may coincide with those of shareholders and the Company. However, the lack of definition of stakeholders, as well as the danger of abuse by management of Social Initiatives in other to promote their own benefit demands to put into place efficient Reporting and Control systems. Existing reporting initiatives are a basic instrument of control of Social and environmental practices. However they lack the uniformity to make them truly effective.

Governance experts and Academics, Governments and Corporations have, at least, two serious challenges ahead: One is to achieve a

\footnotetext{
${ }^{42}$ Social and environmental policy is not going to disappear from the European Union Agenda. Unions and other pressure groups continue to demand stronger social dimension, and Corporate Social Responsibility should form an integral part of the European Union efforts to find innovative and flexible solutions to longstanding social and environmental problem, while maintaining the competitiveness of European Business. This was made explicit by the Commission at European Commission. Promoting a European framework for Corporate Social Responsibility. Green Paper, Brussels, 18.01.2001. COM (2001) 366 final.
} 
consensus on how to define and prioritise the interests of stakeholders. The other is to formulate a comprehensive and efficient generally accepted reporting model to account for corporate actions in favour of non-shareholders constituencies.

\section{References}

1. Berle, A. "For Whom Corporate Managers Are Trustees" Harvard Law Review, num. 44, (1931), 1365,1372

2. Buchholz R.A, and Rosenthal, S B "Social responsibility and Business Ethics" en Frederick RE (Ed), A Companion to Business Ethics, Massachusetts, Blackwell Publishers, 2002.

3. Cooper, S, Corporate Social Performance: A Stakeholder Approach, Ashgate Publishing Cia, London-Hants, UK.

4. Dodd, E.M. "For whom are Corporate Managers Trustees? Harvard Law Review, num. 45, (1932) $1145,1448$.

5. Druker, $\mathrm{P}$ "The new meaning of Corporate Social responsibility", California Management Review, number 26, pages 53-63. 1994.

6. European Commission.

7. Promoting a European framework for Corporate Social Responsibility. Green Paper, Brussels, 18.01.2001. COM (2001) 366 final.

8. "Communication from the Commission concerning Corporate Social Responsibility: A business contribution to Sustainable Development", Brusels 02.07.2002, COM (2002) 0347 final.

9. "Implementing the partnership for Growth and Jobs: making Europe a pole of Excellence on Corporate Social Responsibility" Brussel 22.03.2006. COM (2006) 136 final.

10. Friedman, M Capitalism and Freedom. University of Chicago Press, 1962.

11. Fundacion empresa y Sociedad. FES (2003): Las empresas mejor percibidas por su acción social. Ranking 2003. Fundación Empresa y Sociedad, Madrid [http://www.empresaysociedad.org].

12. Gioia, D A "Practicability, paradigms, and problems in stakeholder theorising", The Academy of Management Review, Vol 24 (2)1999, pages 228232.

13. Graved, M Ownership and Influence, Interdisciplinary Institute of Management, LSE, London, 1995.
14. Hirsch, F Social Limits to Growth, Routledge and Kegan Paul, London and Henley, 1978.

15. Hummels, H., "Organising Ethics: A Stakeholder debate", Journal of Business Ethics, October, Vol 17 (13) 1998, pages 1403-1419.

16. Jensen, $M$ "Corporate Control and the Politics of Finance", Journal of applied corporate finance, Vol 20(2) 1991, pages 13-33.

17. Kaplan R.,S., and Norton, D. P., "The Balanced Scorecard - Measures That Drive Performance", Harvard Business Review, January-February, 1992, pages 71-79.

$18 . \quad$ The balanced Scorecard: Translating Strategy into Action, Harvard Business School Press, Harvard 1996.

$19 . \quad$ "Using the Balanced Scorecard as a Strategic Management System", Harvard Business Review, January-February, 1996, pages 75-85.

20. D.Kinley, J Tadaki, "From Talk to Walk: The Emergence of Human Rights Responsibilities for Corporations at International Law", 44 VA. Journal International Law pages 931, 953, 2004.

21. Murray, A, Corporate Social Responsibility in the Europe Union, Centre for European Reform, London, 2003.

22. Niskamen, W A, "Corporate Governance, pages 337 to 551 in particular 342, Niskamen W A (ed) After Enron: lessons for public policy, Lanham, New York, 2005.

23. Perez Carrillo, E F "Gobierno corporativo en Europa como instrumento de atracción de inversiones y de responsabilidad social", Revista Criterios, Instituto de Estudios Politicos y Sociales, vol. 5 2005. Pages 81102.

24. Sen, A On Ethics and Economics, Blackwell, Oxford, 1987.

25. Sternberg E, Just Business: Business Ethics in Action, Little, Brown and Company, London, 1994.

26. Wallman, S.M.H., "The Proper Interpretation of Corporate Constituency Statutes and Formulation of Director Duties", 21 Stetson Law Review 163, 166 (1991)

27. Warner, E, "Bosses saving our planet can't ignore the bottom line. The Daily Telegraph, business Centre $20^{\text {th }}$ September 2006, page B 6 .

28. Werther, W B Jr and D Chandler, D., Strategic Corporate Social Responsibility. Stakeholders in a Global environment, Thousand Oaks (California)London, 2006 